\author{
M. MoZHAIEv, P. BuSLOV
}

\title{
A METHOD FOR IMPROVING THE QUALITY INDICATORS OF A DISTRIBUTED FORENSIC INFORMATION SYSTEM
}

\begin{abstract}
Subject of research: the process of monitoring the quality indicators of a computer network of a forensic information system using methods for increasing the frequency resolution of acousto-optic spectrum analyzers. The aim of this work is the possibility of increasing the QoS indicators of a computer network by achieving the potential accuracy of estimating the frequencies of two simultaneously arriving radio pulses using the super-Rayleigh resolution method in acousto-optic spectrum analyzers (AOSA). The following tasks are solved in the article: analysis of various information systems of forensic examination and the tasks that they solve; analysis of the use of acousto-optic spectrum analyzers to determine the parameters of the transmitted signal in a distributed forensic system; derivation of an analytical expression for evaluating the potential accuracy of the frequency detuning value of two pulses. The following methods and models are used: models and methods of systems theory (based on the information approach), models and methods for constructing distributed systems and their components in accordance with various hierarchical levels of their organization and operating conditions; models and methods of theories of propagation and interaction of electromagnetic waves with wave structures of various physical nature. The following results were obtained: The analysis has established that forensic information systems are distributed in nature and impose high requirements on the quality of the functioning of telecommunications equipment of the corresponding computer networks $(\mathrm{CN})$. To meet these requirements, it is necessary to improve the systems for monitoring, protecting and transmitting information in the corresponding $\mathrm{CN}$, which is impossible without solving the problem of monitoring signal parameters. Research has been carried out on the use of AOSA to ensure control over communication channels of computer networks. It was found that most of the AOSA frequency resolution methods have limitations associated with the Rayleigh criterion, which significantly limits the potential for frequency separation of pulses. The use of the method of super-Rayleigh resolution of narrow-band pulses in terms of their arrival time is proposed. An analytical expression is obtained to estimate the potential accuracy of determining the value of the detuning in the frequency of two pulses. Conclusions. The forensic information system is a complex heterogeneous distributed system. To improve the efficiency of its functioning, it is necessary to control the parameters of the signal propagating in the network. The use of the super-Rayleigh resolution method in AOSA will increase the resolution of AOSA by increasing the frequency resolution of two non-simultaneous radio pulses of long duration.
\end{abstract}

Keywords: distributed information system; computer network; acousto-optic spectrum analyzer; QoS indicators of computer networks; resolution; super-Rayleigh resolution.

\section{Introduction}

At the moment, in the modern world, there is a colossal amount of ready-to-use information and computing resources that were created at different times. Different approaches were used to develop them. Almost always, when developing a newer information system, you can find and use ready-made in their functions, readymade components that are already working. The problem is that compatibility requirements were not taken into account when creating them. These components do not understand each other; they cannot work together. It is desirable to have a mechanism or set of mechanisms that will make such independently designed computing resources compatible. The main task of such information and computing resources is, first of all, facilitated access to remote resources and control over the sharing of these resources (computers, files, data in a database (DB). Such resources include a variety of distributed information systems (DIS).

A set of computers connected by communication channels can be considered as a software module (application), executed within a separate process. Users and applications work consistently in DIS regardless of where and when this interaction occurs. To do this, DIS must have characteristics such as hiding from users the differences between computers and how they communicate. Another important DIS characteristic is the way in which DIS provides a consistent user (and application) experience. DIS must meet the following requirements: - transparency; - openness; - flexibility; - scalability (extensibility). These requirements fix two essential points: the autonomy of the DIS nodes and the presentation of the system by the user as a single structure. In this case, the main DIS link is software. Diverse software is rapidly developing and penetrating into all spheres of human activity. Forensic expertise is no exception.

The distributed nature of forensic information systems and the importance of information processed by the system impose increased requirements both on the structure of the system itself and on the quality of data transfer between various subsystems. A large number of studies have been devoted to overcoming these problems [1-12].

A significant place in these studies is occupied by the analysis of the impact of the quality of telecommunications equipment on the functioning of DIS forensic examination. The studies carried out in these works have established that in order to increase the efficiency of the DIS forensic examination, it is necessary to ensure a high quality of functioning of the computer network of the information system, which is not possible without improving the corresponding equipment [9 - 17].

Consequently, the improvement of existing systems for the transmission of information and the design of new telecommunication systems is an urgent task to improve the quality of service for the entire IP of forensic examination.

The purpose of this article is to analyze existing models and types of forensic information systems and the 
possibility of increasing the QoS indicators of a computer network by achieving the potential accuracy of estimating the frequencies of two simultaneously arriving radio pulses using the super-Rayleigh resolution method in acousto-optic spectrum analyzers.

1. To solve this problem, it is necessary to solve a number of specific problems:

2. To analyze the various forensic information systems and the tasks they solve.

3 . To conduct an analysis of the use of AOSA to determine the parameters of the transmitted signal in a distributed forensic system.

4. To obtain an analytical expression for evaluating the potential accuracy of the frequency detuning of two pulses.

5. To develop a method to improve the efficiency of a distributed information system

\section{Main part}

\section{Analysis of the construction and functioning of forensic information systems}

Forensic expertise, varied in form and content, is impossible without the use of a variety of sources of information. These are documents in various information systems, including databases. When selecting information, the principles of reliability, relevance, necessary sufficiency and completeness are observed. The principles of creating information systems include simplicity, openness, interactivity, structure, functional distribution, integration, security and automation.

Expert systems are a line of research in the field of artificial intelligence for the creation of computing systems capable of making decisions similar to the decisions of experts in a given subject area [3]. The functioning of a database in forensic science is based on the principles of operational replenishment and relevance, sufficient speed in the search and processing of data, compliance of answers with search queries, as well as ensuring the protection of information. When investigating the situation of an emergency situation (ES), analyzing material evidence, as well as studying an investigative or operational situation, a systematic approach, game theory, queuing, fuzzy sets and other modern approaches to processing complex and diverse information are used. The decision in forensic examination is made in several stages: modeling, building scenes and processes; analysis of situations based on these models; forecasting their changes. Increasingly, modeling is carried out on the basis of three-dimensional models and even using the so-called augmented reality. In traceology and in image analysis, such a model makes it possible to unambiguously identify an object. The objectivity of the examination with such information support is fully realized.

The use of a database in forensic science involves the collection, accumulation, storage, processing and analysis of information. When collecting information, as a rule, special equipment is used, scanners, digital cameras and video cameras, sound recording devices. In some cases, it is still not possible to digitize the information used in the examination. In this case, bullet sleeves, casts of footprints, full-scale collections, etc. are used. Their accumulation, systematization, search and identification is also based on the database. As the main carrier of large amounts of information used to store these databases, the most effective use of hard drives. Sometimes database copies are stored on external hard drives or "in the cloud" on servers that provide access to them over the Internet around the clock. Currently, there are many reference and information funds. The overwhelming majority of them are database-based and are automated information retrieval systems. Forensic institutions [3] use reference and information funds, built in relation to specific types of expertise, as well as for various objects or research methods. However, they are all implemented in the form of automated information retrieval systems based on a database, and are part of the forensic registration system. This system includes subsystems called forensic accounting. Accounts are classified by purpose and features of registration objects.

Thus, the study showed that there are effective information systems in practically all areas of information support for forensic examination. These information systems have a distributed and heterogeneous nature and, in order to ensure the main indicators of the quality of functioning, they place high demands on the quality of the functioning of the telecommunications equipment of the corresponding computer networks $(\mathrm{CN})$. After all, it cannot yet be stated that information systems for the provision of forensic expertise (ISPFE) have the properties of artificial intelligent systems that expert systems possess.

To solve this complex problem, it is necessary to make efforts in all aspects of ISPFE functioning, including to improve the quality of QoS CN. The next section of our article will analyze possible ways to improve QoS through the use of modern methods for determining the parameters of the signal propagating in the network.

2. Analysis of the possibility of using AOSA to determine signal parameters in a computer network.

To successfully solve the problem of electromagnetic compatibility of a large number of currently existing various communication, radio navigation and radar complexes, it is necessary to determine the parameters of radio emission sources as accurately as possible, in real time. The task of measuring the parameters of propagating signals is complicated by the fact that modern radio engineering complexes during operation can change the basic parameters of radiation, such as: frequency, pulse duration, pulse repetition period, and many others. For operational recognition and determination of radio signal parameters, processing methods using acousto-optic interaction are increasingly used. This is due to the specific capabilities of such methods: parallelism, high speed and frequency of optical signal processing, etc. [4, $17,18]$.

The above possibilities are implemented in acoustooptic spectrum analyzers (AOSA), which are distinguished by their simplicity of design and parallel processing of signals in a wide frequency band and 
practically in real time [4]. The advantages of using AOSA for solving spectral analysis problems and expanding the bandwidth of simultaneously analyzed frequencies necessitate a deeper analysis of the resolution of these devices.

Analysis of a number of works $[4,7,14,17,18]$ devoted to the theory of development of devices for acousto-optic conversion and signal processing allows stating the contiguity of such characteristics of frequency accuracy as the accuracy of reading the radio signal frequency and resolution for the class of devices under consideration. In this case, the resolving power of an acousto-optic spectrum analyzer is understood to be its ability to resolve two close frequency components of the analyzed spectrum or two adjacent in frequency radio emission [7, 14, 17]. Resolution is quantitatively defined as the minimum frequency interval between two radio emissions or spectrum components, at which they are reliably separated. The characteristic of the frequency readout accuracy allows one to judge with what accuracy the frequency interval between adjacent frequency components or the true value of each of them can be measured [4].

Indeed, in the practice of designing and constructing acousto-optic and, in particular, optical devices for spectral analysis, the resolution and frequency readout accuracy are determined by the parameters of the instrumental function formed by these devices and the selected resolution criterion. In most cases, to characterize the frequency accuracy of the device, the concept of the Rayleigh criterion is introduced, to determine which the case is considered when the input of an acousto-optic transducer is affected by two harmonic signals spaced apart in frequency by a value of $\Delta \mathrm{f}[4,17]$. This happened historically, by analogy with the resolution of most optical instruments, for example, telescopes. In this case, two optical signals are formed in the focal plane of the device, the intensity distribution of each of which along the plane of the photodetector is described by an apparatus function of the form $\sin 2(\mathrm{x}) / \mathrm{x} 2$, and the linear distance $\Delta \mathrm{x}$ between the maxima of zero orders is proportional to $\Delta \mathrm{f}$. According to the criterion under consideration, the resolution limit of two signals in a diffraction-limited optical system is reached if the maximum of the zero order of one signal coincides with the minimum of the first order of the second. Thus, the resolution limit and the accuracy of the signal frequency reading according to the Rayleigh criterion are ultimately determined by the device itself, namely, it is inversely proportional to the width of its instrumental function.

The analysis of the resolution criterion considered above, given in [4], shows that it is, in essence, focused on qualitative observations, and the value of the resolution obtained on the basis of such a definition does not correspond to modern requirements for measuring technology. So, for example, the well-known opinion that the limit of the resolution and accuracy of the signal frequency reading is determined by the properties of the device and, in particular, by the width of the generated instrumental function, when investigating the procedure for restoring the input from an inaccurately known output turns out to be incorrect for a wide class of input signals with a finite spectrum.

The inconsistency of the Rayleigh concept of resolution with the results of experiments with quantitative measurements led to a wide discussion of the very concept of resolution and an analysis of the corresponding criteria. The results of research in the field of the theory of resolution and presented in $[4,17,18]$ allow us to say that the resolution limit and the accuracy of measuring the frequency reference becomes not a property of the device itself, and is determined, in particular, not by the width of its instrumental function, but by the accuracy of reading output process. In turn, the accuracy of recording the output signals under ideal experimental conditions is determined by fluctuation processes in the equipment. Therefore, only the fluctuation limit of resolution is insurmountable, due to objective physical phenomena (discreteness of the charge, the quantum nature of optical radiation, etc.). Thus, the frequency accuracy of existing acousto-optic spectrum analyzers, the choice of the parameters of photodetectors of which was based on the principles of Rayleigh resolution, can be significantly improved by using special procedures for recording and processing optical signals, taking into account their statistical properties due to the nature of their formation.

Recently, in papers $[17,18]$ devoted to the problem of increasing the resolving power of acousto-optic spectrum analyzers, other physical principles have also been applied. For example, [17] proposed a technique for increasing the resolution of acousto-optic spectrum analyzers taking into account the nonlinear nature of acousto-optic interaction. In this case, the analysis of the acousto-optic interaction proceeding in acousto-optic spectrum analyzers was carried out without integration over time, which leads to smoothing of fluctuations.

In most cases, the frequencies of radio pulses measured in AOSA are so close that it is not possible to distinguish them using either the Rayleigh criterion or other methods. But in pulsed radar there is a method of super-Rayleigh resolution of narrow-band pulses in terms of their arrival time. The basis of this method is the noiseless idealization of the signal mixture and its analytical representation by a polynomial, the degree of which is equal to the number of signal sources, and the roots are uniquely related to their parameters.

3. Evaluation of the potential accuracy of determining the frequency detuning of two pulses.

It is well known, that in most of the currently existing AOSA, the signal is sequentially read from a line of photosensitive elements. Thus, we can assume that there is a vector containing $N$ measurements at points $x_{1}, \ldots, x_{N}$ of a random variable distributed according to Poisson's law $n=\left\{n_{1}, n_{2}, \ldots, n_{N}\right\}$. Each element of the measurement vector is characterized by mathematical expectation $M\left(n_{i}\right)$ and variance $D\left(n_{i}\right)$, and. $\mathrm{M}\left(\mathrm{n}_{\mathrm{i}}\right)=D\left(\mathrm{n}_{\mathrm{i}}\right)=b_{i}, \quad i=1,2, \ldots, N$. 
It is known [10] that $b_{i}$ are functions of the parameters $a, x_{i}, \Delta$ :

$$
b_{i}=\left(\frac{\operatorname{Sin}(a(x+\Delta / 2))}{a(x+\Delta / 2)}\right)^{2}+\left(\frac{\operatorname{Sin}(a(x-\Delta / 2))}{a(x-\Delta / 2)}\right)^{2} \text {, }
$$

where $a-$ is the parameter characterizing the diffraction properties of the spectrum analyzer, and the unknown is the parameter $\Delta$, characterizing the frequency detuning of the two analyzed pulses.

In (1), the amplitude is assumed to be normalized to unity, since taking it into account in the future has no difficulties.

Fig. 1, and fig. 2 show the possible form of the mean value of the vector $\mathrm{n}$, determined by dependence (1) at the values $a=\pi$ and $a=0.5$, respectively (the value $\Delta=1)$.

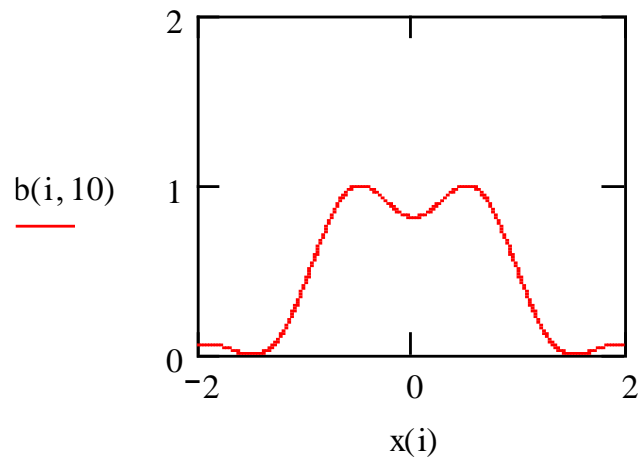

Fig. 1. The average value of the vector $\mathrm{n}$ at $a=\pi$

If the samples are independent of each other, their joint distribution will have the form:

$$
P(\Delta, \underline{n})=\prod_{i=1}^{N} P\left(b_{i}, n_{i}\right),
$$

where

$$
P\left(b_{i}, n_{i}\right)=\frac{e^{-b_{i}} b_{i}^{n_{i}}}{n_{i} !} .
$$

It is required to determine the potential estimation accuracy of the parameter $\Delta$.

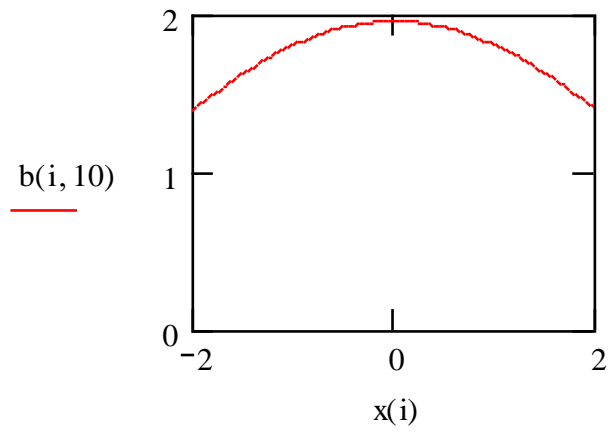

Fig. 2. Average value of vector $n$ at $a=0,5$

The potentially possible variance of the parameter $\Delta$ estimation is determined based on the Rao-Cramer inequality. It is equal to the reciprocal of the expected value (i.e., averaged over realizations) of the second derivative of the logarithm of the distribution function (2), taken with the opposite sign [14]:

$$
\sigma_{\Delta}^{2}=-\overline{\partial^{2} \ln P(\Delta, n) / \partial \Delta^{2}}=1 / \sum_{i=1}^{N}\left(\partial b_{i} / \partial \Delta\right)^{2} / b_{i},
$$

where the bar above the expression means the averaging sign,

$$
\begin{aligned}
& \partial b_{i} / \partial \Delta=\frac{2 \operatorname{Sin}\left(a\left(x_{i}+\Delta / 2\right)\right)}{a^{3}\left(x_{i}+\Delta / 2\right)^{3}}\left[a\left(x_{i}+\Delta / 2\right) \cos (a(x+\Delta / 2))-(a \Delta / 2) \operatorname{Sin}(a(x+\Delta / 2))\right]+ \\
& +\frac{2 \operatorname{Sin}\left(a\left(x_{i}-\Delta / 2\right)\right)}{a^{3}\left(x_{i}-\Delta / 2\right)^{3}}\left[a\left(x_{i}-\Delta / 2\right) \cos (a(x-\Delta / 2))-(a \Delta / 2) \operatorname{Sin}(a(x-\Delta / 2))\right] .
\end{aligned}
$$

Note that the expression for calculating the variance does not contain the second derivatives of $b_{i}$. In practice, the true values of $\Delta$ are unknown, so they are replaced with appropriate estimates. However, here we do not consider the issues of obtaining estimates for the unknown parameter and for the purposes of analyzing the dependence of the potential accuracy on the value of the unknown parameter, we will assume that it is known exactly.

We studied the dependence of the value of the rootmean-square error in estimating the detuning of two pulses in frequency $\sigma_{\Delta}$ on the detuning $\Delta$ at various sampling rates of the parameter $\mathrm{x}$. Discretization of the parameter $\mathrm{x}$ was carried out on the interval [$2 \pi / \mathrm{a}, 2 \pi / \mathrm{a}], \quad$ i.e. $\quad x_{i}=-\frac{2 \pi}{a}+i 4 \pi / a N, \quad$ where $i=1,2, \ldots, N$; where $N$ is the number of samples on the selected interval. The research results for $\mathrm{a}=\pi$ are shown in fig. 3 and fig. 4, and in fig. 5 and fig. 6 - for $\mathrm{a}=0.5$. The number of samples was chosen equal to 10 and 100 .

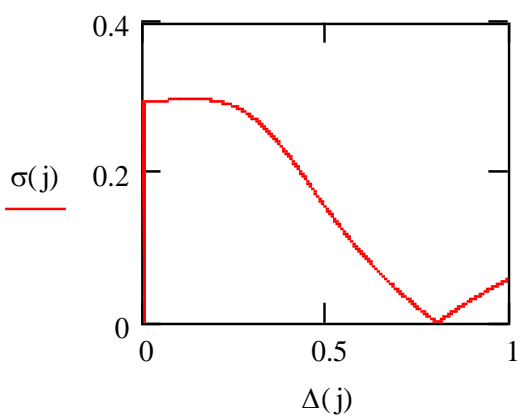

Fig. 3. Dependence of $\sigma_{\Delta}$ on the detuning value $\Delta$ at $N=10$, $a=\pi$ 


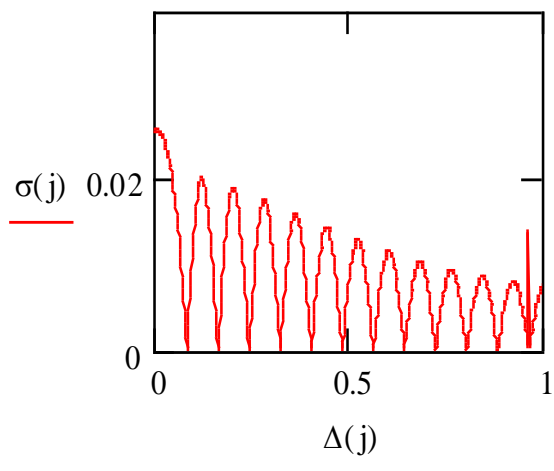

Fig. 4. Dependence of $\sigma_{\Delta}$ on the detuning value $\Delta$ at $N=100$, $a=\pi$

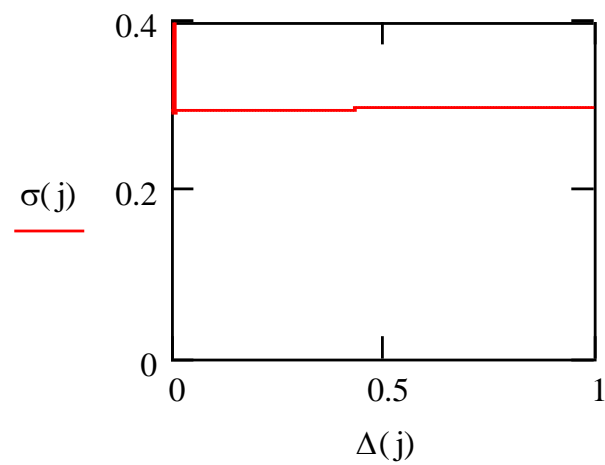

Fig. 5. Dependence of $\sigma_{\Delta}$ on the detuning value $\Delta$ at $N=10$, $\mathrm{a}=0,5$

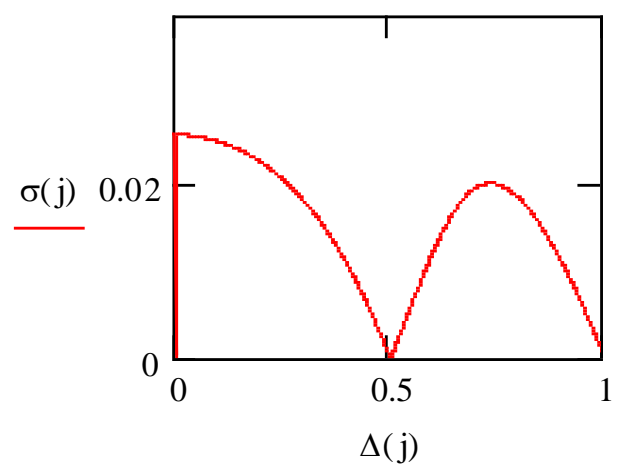

Fig. 6. Dependence of $\sigma_{\Delta}$ on the detuning value $\Delta$ at $N=100$, $\mathrm{a}=0,5$

Analysis of figs. 3 - 6 shows that the dependence of the root-mean-square error in estimating the detuning in frequency on its value is periodic. This is natural, since the terms in (4) are also periodic functions. However, as the value a decreases, the periodicity in the selected interval becomes less noticeable (figs. 1, 2), which explains the difference in the nature of the curves in figs. 3,5 . With a small number of discrete $(\mathrm{N}=10$, fig. 3,5$)$ and a small detuning $\Delta<0.4$, the root mean square error of the estimated parameter is commensurate with its value. This means that reliable estimates are unlikely to be obtained under these conditions. With an increase in the number of samples on the selected interval $(\mathrm{N}=100$, figs. $4,6)$, the value of the root-mean-square error is less than $10 \%$ of the value of the estimated parameter over the entire interval.

\section{The method of increasing the efficiency of a} distributed information system

The results obtained in the previous part of the article allow us to propose a method for controlling the frequency of the signal propagating in the ISPFE information transmission channels. As noted above, this method is based on the use of super-Rayleigh resolution of narrow-band pulses, which provides up to $12 \%$ increase in the frequency measurement accuracy in comparison with known methods. Thus, it is possible to propose a method for increasing the operability of a distributed information system, which is based on the use of AOSA, the optimal processing of a signal functioning in the ISPFE computer network, which leads to a significant improvement in the resolution and, in turn, leads to a decrease in information loss caused by electromagnetic problems, compatibility and synchronization of pulses in the investigated computer networks.

\section{Conclusions}

The article carried out studies of the forensic information system, which confirmed that this system is distributed and heterogeneous, which explains the complexity of the complete automation of this system. As part of the analysis, it was found that for the effective functioning of the forensic information system, it is necessary to fulfill rather stringent requirements for the computer network that provides information exchange.

It is proposed to monitor the efficiency of the computer network of the forensic information system based on the determination of the main parameters of the signal, which ensures the transmission of information in communication channels.

When monitoring the frequency of pulses propagating in communication channels, the article proposes the use of acousto-optic spectralizers, which provide fairly high frequency resolution values.

As a result of the analysis of the classical (Rayleigh) approach to determining the resolution of AOSA, it was found that the frequency resolution can be significantly improved by applying special procedures for recording and processing optical signals, taking into account their statistical properties due to the nature of their formation.

The article substantiates the possibility of using super-Rayleigh frequency resolution of pulses in acousto-optic spectrum analyzers. An expression is obtained for estimating the potential accuracy of the frequency detuning of two pulses. Analysis of potential accuracy calculations shows that for the practical use of the idea of super-Rayleigh frequency resolution of pulses in acousto-optic spectrum analyzers, it is necessary to provide the required sampling frequency.

The article proposes a method for increasing the efficiency of a distributed information system, which is based on the use of AOSA, the optimal processing of a signal operating in the ISPFE computer network. 


\section{References}

1. Lamport, L. "Distributin", available at : http://research.microsoft.com/enus/um/people/lamport/pubs/distributed-system.txt (last accessed: 06.11.2016).

2. Tanenbaum E., Van-Steen, M. (2003), Distributed Systems. The principles and paradigms, SPb. : Peter, 877 p.

3. Radchenko, G. I. (2012), Distributed Computing, Chelyabinsk : Photographer, 184 p.

4. Mozhaiev, M., Melashchenko, O., Roh, V. Usatenko M. (2020), "Means of improving the quality of service of the computer network of the forensic information system", Innovate Technologies and Scientific Solutions for Industries, No. 2 (12), P. 57-65. DOI: https://doi.org/10.30837/2522-9818.2020.12.057

5. Kuchuk, G. (2007), "Traffic management of multiservice distributed telecommunication network" ["Upravlinnya trafikom mul'tyservisnoyi rozpodilenoyi telekomunikatsiynoyi merezhi"], Control, navigation and communication systems, Kyiv : TsNII NiU, Issue 2, P. $18-27$.

6. Kuchuk, G., Ruban, I., Davikoza, O. (2013), "Conceptual approach to synthesis of information and telecommunication network structure" ["Kontseptual'nyy pidkhid do syntezu struktury informatsiyno-telekomunikatsiynoyi merezhi"], Systems of information processing: collection of scientific works, No. 7 (114), P. 106-112.

7. Kosenko, V. (2017), "Mathematical model of optimal distribution of applied problems of safety-critical systems over the nodes of the information and telecommunication network", Advanced Information Systems, Vol. 1, No. 2, P. 4-9. DOI: https://doi.org/10.20998/25229052.2017.2.01

8. Kovalenko, A., Kuchuk, G. (2018), "Methods of synthesis of information and the technical structure of structural systems governs a critical situation" ["Metody sinteza informacii i tekhnicheskoj struktury strukturnyh sistem upravlyaet kriticheskoj situaciej"], Advanced Information Systems, Vol. 2, No. 1, P. 22-27. DOI: https://doi.org/10.20998/2522-9052.2018.1.04

9. Lemeshko, O., Yevdokymenko, M., Yeremenko, O. (2019), "Model of data traffic QoS fast rerouting in infocommunication networks", Innovative Technologies and Scientific Solutions for Industries, No. 3 (9), P. 127-134. DOI: https://doi.org/10.30837/2522-9818.2019.9.127

10. Kuchuk, G., Kharchenko, V., Kovalenko, A., Ruchkov, E. (2016), "Approaches to selection of combinatorial algorithm for optimization in network traffic control of safety-critical systems", East-West Design \& Test Symposium (EWDTS), P. 1-6. DOI: https://doi.org/10.1109/EWDTS.2016.7807655

11. Mozhaev, O., Kuchuk, H., Kuchuk, N., Mozhaev, M., Lohvynenco, M. (2017), "Multiservise network security metric", IEEE Advanced information and communication technologies-2017, Proc. of the 2th Int. Conf., Lviv, P. 133-136.

12. Kosenko, V. (2017), "Principles and structure of the methodology of risk-adaptive management of parameters of information and telecommunication networks of critical application systems", Innovative Technologies and Scientific Solutions for Industries, No. 1 (1), P. 46-52. DOI: https://doi.org/10.30837/2522-9818.2017.1.046

13. Kuchuk, G.., Kovalenko, A., Mozhaev, A. (2010), "An Approach to Development of Complex Metric for Multiservice Network Security Assessment", Statistical Methods Of Signal and Data Processing (SMSDP - 2010): Proc. Int. Conf., October 13-14, 2010, Kyiv : NAU, RED, IEEE Ukraine section joint SP, P. 158-160.

14. Kliuiev, O., Mozhaiev, M., Uhrovetskyi, O., Mozhaiev, O., Simakova-Yefremian, E. (2019), "Method of forensic research on image for finding touch up on the basis of noise entropy", 2019 3rd International Conference on Advanced Information and Communications Technologies, AICT 2019 - Proceedings.

15. Davydovskyi, Y., Reva, O., Artiukh, O., Kosenko, V. (2019), "Simulation of computer network load parameters over a given period of time", Innovative Technologies and Scientific Solutions for Industries, No. 3 (9), P. 72-80. DOI: https://doi.org/10.30837/25229818.2019.9.072

16. Kuchuk, G., Kovalenko, A., Komari, I. E., Svyrydov, A., Kharchenko, V. (2019), "Improving big data centers energy efficiency: Traffic based model and method", Studies in Systems, Decision and Control, Springer Nature Switzerland AG, Vol. 171, P. 161-183. DOI: http://doi.org/10.1007/978-3-030-00253-4_8

17. Mozhaiev, M., Kuchuk, N., Usatenko M. (2019), "The method of jitter determining in the telecommunication network of a computer system on a special software platform", Innovative Technologies and Scientific Solutions for Industries, No. 4 (10), P. 134-140. DOI: https://doi.org/10.30837/2522-9818.2019.10.134

18. Rudnytsky, V., Mozhaiev, M. and Kuchuk, N. (2020) "Method for the diagnostics of synchronization disturbances in the telecommunications network of a critical used computer system", Innovative Technologies and Scientific Solutions for Industries, No. 1 (11), P. 172-180. DOI: https://doi.org/10.30837/2522-9818.2020.11.172

Received 26.11.2020

Відомості про авторів / Сведения об авторах / About the Authors

Можаєв Михайло Олександрович - кандидат технічних наук, Харківський науково-дослідний інститут судових експертиз ім. засл. проф. М.С. Бокаріуса, завідувач сектору комп'ютерно-технічних та телекомунікаційних досліджень, Харків, Україна; email: mikhail.mozhayev@ hniise.gov.ua; ORCID: http://orcid.org/0000-0003-1566-9260.

Можаев Михаил Александрович - кандидат технических наук, Харьковский научно-исследовательский институт судебных экспертиз им. засл. проф. Н.С. Бокариуса, заведующий сектора компьютерно-технических и телекоммуникационных исследований, Харьков, Украина.

Mozhaiev Mykhailo - PhD (Engineering Sciences), Kharkiv SRI Examinations named Dist. prof. N.S. Bokarius, Head of the Department of Computer Engineering and Telecommunication, Kharkiv, Ukraine.

Буслов Павло Володимирович - Харківський національний університет радіоелектроніки, здобувач, Харків, Україна; email: p.buslov@ukr.net; ORCID: https://orcid.org/0000-0002-2558-4984. Украина.

Буслов Павел Владимирович - Харьковский национальный университет радиоэлектроники, соискатель, Харьков,

Buslov Pavlo - Kharkiv National University of Radio Electronics, Aspirant, Kharkiv, Ukraine. 


\section{МЕТОД ПІДВИЩЕННЯ ПОКАЗНИКІВ ЯКОСТІ РОЗПОДІЛЕНОЇ ІНФОРМАЦИЙНӦ̈ СИСТЕМИ СУДОВОЇ ЕКСПЕРТИЗИ}

Предмет дослідження: процес контролю показників якості комп'ютерної мережі інформаційної системи судової експертизи із застосуванням методів підвищення роздільної здатності по частоті акустооптичних аналізаторів спектра. Метою роботи $\epsilon$ можливість підвищення показників QoS комп'ютерної мережі за рахунок досягнення потенційної точності оцінювання частот двох радіоімпульсів, що прийшли одночасно, при використанні методу понадрелеевского дозволу в акустооптичних аналізаторах спектра (АОАС). У статті вирішуються наступні завдання: аналіз різних інформаційних систем судової експертизи і завдань, які вони вирішують; аналіз використання акустооптичних аналізаторів спектра для визначення параметрів сигналу, що передається в розподіленої системі судової експертизи; виведення аналітичного виразу для оцінки потенційної точності величини розладу по частоті двох імпульсів. Використовуються такі методи і моделі: моделі та методи теорії систем (на базі інформаційного підходу), моделі і методи побудови розподілених систем і їх компонентів у відповідності з різними ієрархічними рівнями їх організації та умов експлуатації; моделі і методи теорій поширення i взаємодії електромагнітних хвиль 3 хвильовими структурами різної фізичної природи. Були отримані наступні результати: Проведений аналіз встановив, що інформаційні системи судової експертизи мають розподілений характер і висувають високі вимоги до якості функціонування телекомунікаційного обладнання відповідних комп'ютерних мереж (КМ). Для забезпечення цих вимог необхідне вдосконалення систем контролю, захисту і передачі інформації в відповідних КМ, яке неможливо без вирішення проблеми контролю параметрів сигналу. Проведено дослідження використання АОАС для забезпечення контролю над каналами зв'язку комп'ютерних мереж. Встановлено, що більшість методів покращення роздільної здатності АОАС має обмеження, пов'язані із застосуванням критерію Релея, що істотно обмежує потенційну можливість поділу імпульсів по частоті. Запропоновано використання методу понадрелеевского дозволу вузькосмугових імпульсів по часу їх приходу. Отримано аналітичний вираз для оцінки потенційної точності визначення величини розладу по частоті двох імпульсів. Висновки. Інформаційна система судової експертизи є складною гетерогенної розподіленої системою. Для підвищення ефективності ії функціонування необхідно здійснювати контроль за параметрами сигналу, що поширюється в мережі. Використання методу понадрелеевского дозволу в АОАС дозволить підвищити роздільну здатність АОАС за рахунок підвищення дозволу по частоті двох радіоімпульсів, що прийшли неодночасно, великої тривалості.

Ключові слова: розподілена інформаційна система; комп'ютерна мережа; акустооптичний аналізатор спектру; показники QoS комп'ютерних мереж; роздільна здатність; понадрелеевский дозвіл.

\section{МЕТОД ПОВЫШЕНИЯ ПОКАЗАТЕЛЕЙ КАЧЕСТВА РАСПРЕДЕЛЕННОЙ ИНФОРМАЦИОННОЙ СИСТЕМЫ СУДЕБНОЙ ЭКСПЕРТИЗЫ}

Предмет исследования: процесс контроля показателей качества компьютерной сети информационной системы судебной экспертизы с применением методов повышения разрешающей способности по частоте акустооптических анализаторов спектра. Целью работы является возможность повышения показателей QoS компьютерной сети за счет достижения потенциальной точности оценивания частот двух одновременно пришедших радиоимпульсов при использовании метода сверхрэлеевского разрешения в акустооптических анализаторах спектра (АОАС). В статье решаются следующие задачи: анализ различных информационных систем судебной экспертизы и задач, которые они решают; анализ использования акустооптических анализаторов спектра для определения параметров передаваемого сигнала в распределенной системе судебной экспертизы; вывод аналитического выражения для оценки потенциальной точности величины расстройки по частоте двух импульсов. Используются следующие методы и модели: модели и методы теории систем ( на базе информационного подхода), модели и методы построения распределенных систем и их компонентов в соответствии с различными иерархическими уровнями их организации и условий эксплуатации; модели и методы теорий распространения и взаимодействия электромагнитных волн с волновыми структурами различной физической природы. Были получены следующие результаты: Проведенный анализ установил, что информационные системы судебной экспертизы имеют распределенный характер и предъявляют высокие требования к качеству функционирования телекоммуникационного оборудования соответствующих компьютерных сетей (КС). Для обеспечения этих требований необходимо совершенствование систем контроля, защиты и передачи информации в соответствующих КС, которое невозможно без решения проблемы контроля параметров сигнала. Проведены исследования использования АОАС для обеспечения контроля над каналами связи компьютерных сетей. Установлено, что большинство методов разрешения по частоте АОАС имеет ограничения, связанные с применением критерия Рэлея, что существенно ограничивает потенциальную возможность разделения импульсов по частоте. Предложено использование метода сверхрэлеевского разрешения узкополосных импульсов по времени их прихода. Получено аналитическое выражение для оценки потенциальной точности определения величины расстройки по частоте двух импульсов. Выводы. Информационная система судебной экспертизы является сложной гетерогенной распределенной системой. Для повышения эффективности ее функционирования необходимо осуществлять контроль за параметрами сигнала, распространяющегося в сети. Использование метода сверхрэлеевского разрешения в АОАС позволит повысить разрешающую способность АОАС за счет повышения разрешения по частоте двух неодновременных радиоимпульсов большой длительности.

Ключевые слова: распределенная информационная система; компьютерная сеть; акустооптический анализатор спектра; показатели QoS компьютерных сетей; разрешающая способность; сверхрэлеевское разрешение.

\section{Бібліографічні описи / Bibliographic descriptions}

Можаєв М. О., Буслов П. В. Метод підвищення показників якості розподіленої інформаційної системи судової експертизи. Сучасний стан наукових досліджень та технологій в промисловості. 2020. № 4 (14). С. 71-77. DOI: https://doi.org/10.30837/ITSSI.2020.14.071

Mozhaiev, M., Buslov, P. (2020), "A method for improving the quality indicators of a distributed forensic information system", Innovative Technologies and Scientific Solutions for Industries, $\quad$ No. 4(14), P.71-77. DOI: https://doi.org/10.30837/ITSSI.2020.14.071 